Franciszek Bolechowski

Uniwersytet Ekonomiczny w Krakowie

franciszek.bolechowski93@gmail.com

(D) https://orcid.org/0000-0002-5546-3817

\title{
Socjodemograficzne determinanty aktywności turystycznej beneficjentów programu socjalnego Rodzina 500+ w Polsce
}

\section{Streszczenie}

Głównym celem rozdziału jest wskazanie socjodemograficznych determinant aktywności turystycznej beneficjentów programu socjalnego Rodzina 500+ w Polsce. W oparciu o wyniki badań przeprowadzonych od stycznia do maja 2020 r. za pomocą sondażu diagnostycznego wśród 64 Polaków korzystających z tego rodzaju wsparcia socjalnego pozytywnie zweryfikowano tezę główną mówiącą o tym, że po zaspokojeniu potrzeb podstawowych na pewnym poziomie rodziny mogą sobie pozwolić na konsumpcję według upodobania, a w jej ramach na aktywność turystyczną lub częstsze jej podejmowanie. Ponadto, stosując test zależności chi-kwadrat Pearsona, potwierdzono następujące hipotezy cząstkowe: 1. Wraz ze wzrostem miesięcznego dochodu na członka rodziny wzrasta częstotliwość wyjazdów turystycznych. 2. Im liczniejsze gospodarstwo domowe, tym rzadziej jego członkowie podróżują za granicę. 3. Im wyższe wykształcenie rodzica, tym częściej rodzina wyjeżdża w celach poznawczych. Część empiryczną poprzedził przegląd piśmiennictwa na temat wpływu pomocy socjalnej na gospodarkę i rynek.

\section{Wprowadzenie}

Obecna sytuacja demograficzno-ekonomiczna w Polsce związana jest z dwoma zagrożeniami, tj.: pułapką niskiej dzietności oraz pułapką średniego dochodu (Jodko, 2017, s. 80-90). Pierwsza z nich wynika z ukształtowania nowych wzorców, które odnoszą się do modelu rodziny opartego na jednodzietności lub bezdzietności. Taki stan rzeczy spowodowany jest przemianami świadomości społecznej, 
stylu życia i wyznawanych wartości (Sołdra-Gwiżdż, 2017, s. 39). Z kolei pułapka średniego dochodu związana jest $z$ występowaniem sytuacji, w której historyczne tempo wzrostu gospodarczego zwalnia na tyle trwale, że znacząco spowalnia lub nawet uniemożliwia zbliżenie poziomu wielu państw do poziomu krajów o wysokim dochodzie narodowym (Fic i in., 2016, s. 129). Zagrożenia te, w połączeniu ze wzrostem długości życia (wynikającym z poprawy warunków bytowych i zdrowia) oraz zwiększającym się ruchem przestrzennym (migracją za granicę ludzi młodych w wieku 25-35 lat), spowodowały wzrost liczby osób starszych w społeczeństwie (Organiściak-Krzykowska, 2018, s. 131-132). Aby zapobiec pogłębianiu się tego zjawiska i poprawić strukturę demograficzno-ekonomiczną, poszczególne państwa wprowadzają rozmaite rozwiązania. Rząd polski zaproponował w tym względzie 1 kwietnia 2016 r. program socjalny typu Rodzina 500+. Jego efektem jest wzrost konsumpcji Polaków (Liszatyński, 2017, s. 211), a przez to rozwój podaży wielu produktów (takich jak: artykuły żywnościowe, sprzęt RTV, AGD i IT, materiały budowlane, artykuły wyposażenia wnętrz itd.). Po zaspokojeniu potrzeb podstawowych na pewnym poziomie rodziny mogą bowiem pozwolić sobie na konsumpcję według upodobania. W jej ramach na szczególną uwagę zasługuje aktywność turystyczna i częstotliwość jej podejmowania.

Celem pracy jest identyfikacja socjogeograficznych uwarunkowań kształtujących uczestnictwo w ruchu turystycznym beneficjentów programu socjalnego Rodzina $500+$. Wykorzystując wyniki badań przeprowadzonych od stycznia do maja 2020 r. za pomocą sondażu diagnostycznego wśród 64 Polaków pobierających tego rodzaju świadczenia, postanowiono potwierdzić (lub odrzucić) następujące hipotezy cząstkowe: 1 . Wraz ze wzrostem miesięcznego dochodu na członka rodziny wzrasta częstotliwość wyjazdów turystycznych. 2. Im liczniejsze gospodarstwo domowe, tym rzadziej jego członkowie podróżują za granicę. 3. Im wyższe wykształcenie rodzica, tym częściej rodzina wyjeżdża w celach poznawczych. Do weryfikacji hipotez użyto testu chi-kwadrat Pearsona.

Analizę empiryczną poprzedziła kwerenda literatury dotyczącej skutków wprowadzenia świadczeń Rodzina 500+ w Polsce.

\section{Przegląd literatury}

W literaturze przedmiotu istnieje znaczna liczba publikacji poświęconych programowi socjalnemu Rodzina 500+ i jego odniesieniom do wielu aspektów życia. Odnaleźć można artykuły zawierające ocenę mikroekonomicznych efektów dofinansowania publicznego w zakresie utrzymana dzieci $z$ tego programu (Liszatyński, 2017, s. 211). Pewna część publikacji traktuje o tym, że program 500+ realizowany w formie gotówkowej zapewnia większą użyteczność konsumpcji niż wypłacanie jego równowartości w bonach lub też zwolnienia z podatku VAT produktów spożywczych czy artykułów dziecięcych. Taka pomoc socjalna ma ponadto charakter bardziej prorynkowy niż przeznaczenie środków potrzebnych na jego realizację, np. na bezpłatne przedszkola i żłobki (Brzęczek, 2019). Innym przykładem publikacji dotyczących programu socjalnego Rodzina $500+$ są te, w których 
poruszono problematykę jego wpływu na poziom dochodów rozporządzalnych (Wojciuk, 2018) czy też stymulowanie wzrostu demograficznego (Puślecki, 2016). Interesujące są ponadto opracowania mówiące o wpływie programu 500+ na podaż pracy kobiet w Polsce (Magda i in., 2018) oraz o negatywnych skutkach takiej pomocy socjalnej (Dziwosz, 2017). Brak jednak w literaturze analizy socjodemograficznych determinant aktywności turystycznej beneficjentów programu Rodzina 500+. Niniejszy rozdział wypełnia tę lukę badawczą.

\section{Metodyka badań}

W celu określenia, które cechy socjodemograficzne beneficjentów programu Rodzina 500+ wpływają na uczestnictwo w ruchu turystycznym, wykorzystano wyniki badań przeprowadzonych od stycznia do maja 2020 r. za pomocą sondażu diagnostycznego wśród 64 Polaków pobierających tego rodzaju świadczenia socjalne. Respondentów zapytano m.in., ile razy w ciągu roku podróżują, czy są to wyjazdy krajowe czy zagraniczne oraz $\mathrm{w}$ jakim celu je odbywają. W opracowaniu do analizy wykorzystano 6 cech socjodemograficznych osób badanych $\left(X_{u}\right)$, tj. wiek, płeć, wykształcenie, wielkość miejsca zamieszkania, liczbę osób w gospodarstwie domowym oraz miesięczny dochód brutto na członka rodziny. $\mathrm{Na}$ podstawie uzyskanych wyników postanowiono zweryfikować następujące hipotezy badawcze:

- $\mathrm{H}_{\mathrm{A}}$ : Wraz ze wzrostem miesięcznego dochodu na członka rodziny wzrasta częstotliwość wyjazdów turystycznych.

- $\mathrm{H}_{\mathrm{B}}$ : Im liczniejsze gospodarstwo domowe, tym rzadziej jego członkowie podróżują za granicę.

- $\mathrm{H}_{\mathrm{C}}$ : Im wyższe wykształcenie rodzica, tym częściej rodzina wyjeżdża w celach poznawczych.

Postawiono 18-krotnie (dla każdej pary zmiennych $Y_{1}$ i $X_{u}, Y_{2}$ i $X_{u}$ oraz $Y_{3}$ i $X_{u}$ ) następujące hipotezy statystyczne: $\mathrm{H}_{0}$ - częstotliwość wyjazdów turystycznych $\left(Y_{1}\right)$, uczestnictwo w podróżach zagranicznych $\left(Y_{2}\right)$ oraz wyjazd w celu poznawczym $\left(Y_{3}\right)$ nie zależą od danej cechy socjodemograficznej beneficjenta programu socjalnego Rodzina $500+\left(X_{u}\right)$ oraz $\mathrm{H}_{1}$ jako hipotezę alternatywną. Do ich weryfikacji użyto testu chi-kwadrat Pearsona. Przyjmując, zgodnie z regułami powszechnie stosowanymi $\mathrm{w}$ ekonomii, istotność na poziomie $\alpha=0,05$, przy prawdopodobieństwie testowym $p$ mniejszym od 0,05 , należało odrzucić hipotezę $\mathrm{H}_{0}$ i przyjąć hipotezę $\mathrm{H}_{1}$ W przeciwnym razie nie było podstaw do odrzucenia hipotezy $\mathrm{H}_{0}$. Uzyskane wyniki prezentuje tabela 1 . Po przeanalizowaniu zawartych w niej danych można wywnioskować, że częstotliwość wyjazdów turystycznych $\left(Y_{1}\right)$ istotnie determinują 2 z 6 cech socjodemograficznych $\left(X_{u}\right)$ - nie jest ona zależna od płci, wieku, wielkości miejsca zamieszkania oraz liczby osób w gospodarstwie domowym.

Uczestnictwo w podróżach zagranicznych $\left(Y_{2}\right)$ istotnie zależy z kolei od 4 z 6 cech (nieistotne okazały się: wiek i wielkość miejsca zamieszkania). Natomiast na cel poznawczy podróżowania istotnie wpływa tylko jedna cecha - wykształcenie 
Tabela 1. Wysokość prawdopodobieństwa testowego $p$ dla zależności pomiędzy częstotliwością wyjazdów turystycznych, uczestnictwem w podróżach zagranicznych oraz celem poznawczym wyjazdów a cechami socjodemograficznymi beneficjentów programu socjalnego Rodzina $500+\left(X_{u}\right)^{*}$

\begin{tabular}{|c|c|c|c|}
\hline $\begin{array}{c}\text { Cechy } \\
\text { socjodemograficzne } \\
\left(X_{u}\right)\end{array}$ & $\begin{array}{c}\text { Częstotliwość } \\
\text { wyjazdów } \\
\text { turystycznych }\left(Y_{1}\right)\end{array}$ & $\begin{array}{c}\text { Uczestnictwo } \\
\text { w podróżach } \\
\text { zagranicznych }\left(Y_{2}\right)\end{array}$ & $\begin{array}{c}\text { Cel poznawczy } \\
\text { podróżowania }\left(Y_{3}\right)\end{array}$ \\
\hline Płeć $\left(X_{1}\right)$ & $p=0,90172$ & $p=0,03802$ & $p=0,76057$ \\
\hline Wiek $\left(X_{2}\right)$ & $p=0,92198$ & $p=0,07488$ & $p=0,51100$ \\
\hline Wykształcenie $\left(X_{3}\right)$ & $p=0,00381$ & $p=0,00112$ & $p=0,03514$ \\
\hline $\begin{array}{l}\text { Wielkość miejsca } \\
\text { zamieszkania }\left(X_{4}\right)\end{array}$ & $p=0,78073$ & $p=0,52967$ & $p=0,65606$ \\
\hline $\begin{array}{l}\text { Liczba osób } \\
\text { w gospodarstwie } \\
\text { domowym }\left(X_{5}\right)\end{array}$ & $p=0,10025$ & $p=0,04575$ & $p=0,32132$ \\
\hline $\begin{array}{l}\text { Miesięczny dochód } \\
\text { brutto na } 1 \text { członka } \\
\text { rodziny }\left(X_{6}\right)\end{array}$ & $p=0,00471$ & $p=0,00212$ & $p=0,15108$ \\
\hline
\end{tabular}

*Pogrubioną czcionką oznaczono zależności istotne statystycznie.

Źródło: obliczenia własne na podstawie przeprowadzonych badań.

(nieistotne są: wiek, płeć, wielkość miejsca zamieszkania, liczba osób w gospodarstwie domowym oraz miesięczny dochód brutto na 1 członka rodziny).

\section{Wyniki badań}

Analizując częstotliwości wyjazdów turystycznych w zależności od wysokości miesięcznego dochodu brutto na 1 członka rodziny (zob. ryc. 1), należy stwierdzić, że w przypadku osób deklarujących dochody na poziomie do 1000 zł częstotliwość wyjazdów turystycznych rozłożyła się równomiernie - po 1/4 respondentów stanowiły osoby wyjeżdżające $\mathrm{w}$ celach turystycznych raz na kilka lat, co dwa lata, raz na rok i dwa razy w roku.

Wśród badanych deklarujących zarobki w przedziale 1001-2000 zł największą grupę stanowiły osoby wyjeżdżające dwa razy w roku (blisko $2 / 5$ respondentów tej grupy). Prawie $30 \%$ ankietowanych $z$ tego segmentu wyjeżdżało raz na rok. Podróżujący raz na kilka lat oraz trzy razy w roku stanowili podobne części tej zbiorowości (odpowiednio 11\% i 17\%). Osoby podróżujące częściej niż trzy razy $\mathrm{w}$ roku tworzyły natomiast niespełna $6 \%$ tego segmentu.

Spośród osób deklarujących wielkość dochodów na poziomie 2001-3000 zł największy udział miały te, wyjeżdżające w celach turystycznych dwa razy w roku (ponad 2/5 badanych). Drugą grupą pod względem liczebności były osoby podróżujące raz na rok (30\%). Osoby uczestniczące w wyjazdach trzy razy w roku i częściej niż trzy razy w roku stanowiły taki sam odsetek w tej grupie (po 13\%).

Analizując przedział w zakresie 3001-4000 zł deklarowanego miesięcznego dochodu przypadającego na 1 członka rodziny, należy stwierdzić, że dokładnie 


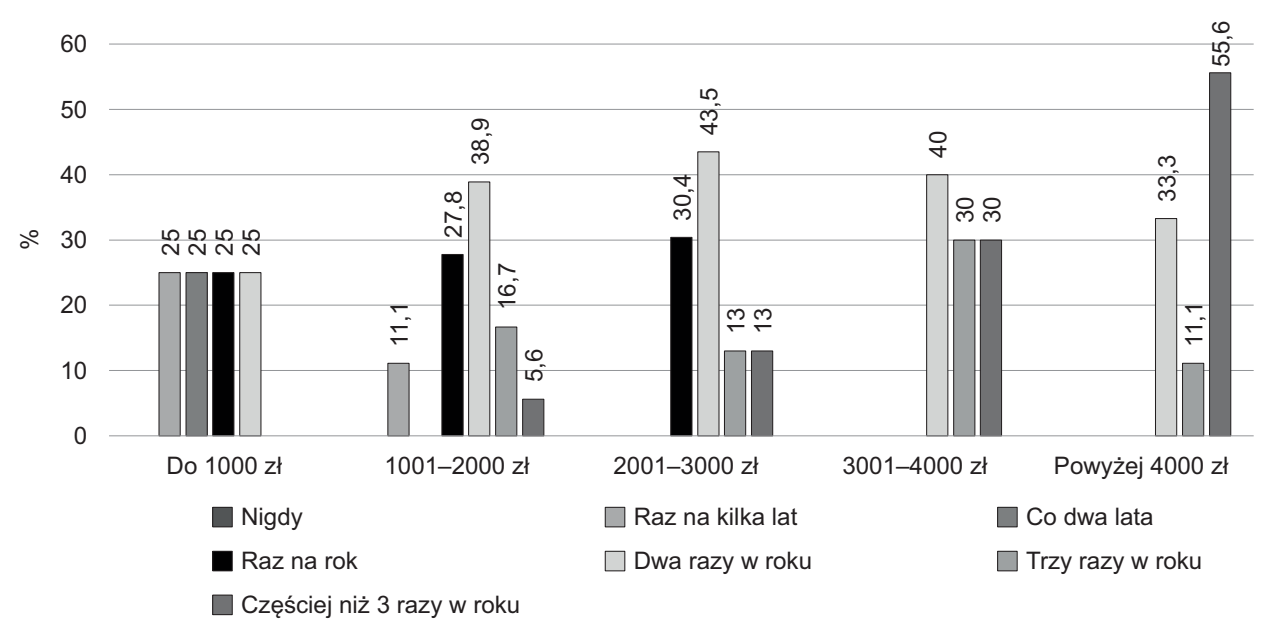

Ryc. 1. Częstotliwość wyjazdów turystycznych w zależności od wysokości miesięcznego dochodu brutto na 1 członka rodziny

Źródło: opracowanie własne na podstawie przeprowadzonych badań.

2/5 osób z tej grupy wyjeżdżało w celach turystycznych dwa razy w roku. Wysoki udział miały też osoby podróżujące trzy razy w roku i częściej niż trzy razy w roku (po 30\%).

Wśród ankietowanych dysponujących kwotą miesięcznego dochodu na 1 członka rodziny powyżej 4000 zł ponad połowę stanowiły osoby wyjeżdżające w celach turystycznych częściej niż trzy razy w roku. Ponad 30\% osób wyjeżdżało dwa razy w roku, a ponad $10 \%$ - trzy razy w roku.

Uwzględniając fakt, że wraz ze wzrostem miesięcznego dochodu na 1 członka rodziny maleje odsetek osób wyjeżdżających raz na kilka lat i co dwa lata (z 25\% na $0 \%$ ), a wzrasta początkowo udział odpowiedzi „raz na rok” (z 25\% na 30\%) i „dwa razy w roku” (z 25\% na 44\%), następnie wskazań na „trzy razy w roku” (z 13\% na 30\%) i dalej - deklaracji „wyjeżdżam częściej niż trzy razy w roku” (z 5\% na 55\%), można uznać, że pierwsza hipoteza cząstkowa $\left(\mathrm{H}_{\mathrm{A}}\right)$ została potwierdzona: wraz ze wzrostem miesięcznego dochodu na członka rodziny wzrasta częstotliwość wyjazdów turystycznych.

Analizując z kolei zależności pomiędzy liczbą osób w gospodarstwie domowym a częstotliwością wyjazdów zagranicznych (zob. ryc. 2), należy stwierdzić, że turystykę zagraniczną uprawiało ponad 3/4 respondentów, u których liczba osób w gospodarstwie domowym wynosi 3 , ponad $63 \%$ badanych, w których rodzinie znajdowało się 4 członków, oraz ponad $46 \%$ ankietowanych z gospodarstw domowych, w skład których wchodziło 5 członków. Najmniejszy odsetek badanych biorących udział w podróżach zagranicznych (ok. 14\%) pochodził z sześcioosobowych gospodarstw domowych. Tym samym założona na wstępie hipoteza $\mathrm{H}_{\mathrm{B}}$ mówiąca, że im liczniejsze gospodarstwo domowe, tym rzadziej jego członkowie podróżują za granicę, została empirycznie potwierdzona.

Rozpatrując trzecią hipotezę $\left(\mathrm{H}_{c}\right)$, trzeba zauważyć, że wykształcenie rodziców ma znaczący wpływ na podejmowanie wyjazdów turystycznych w celach 


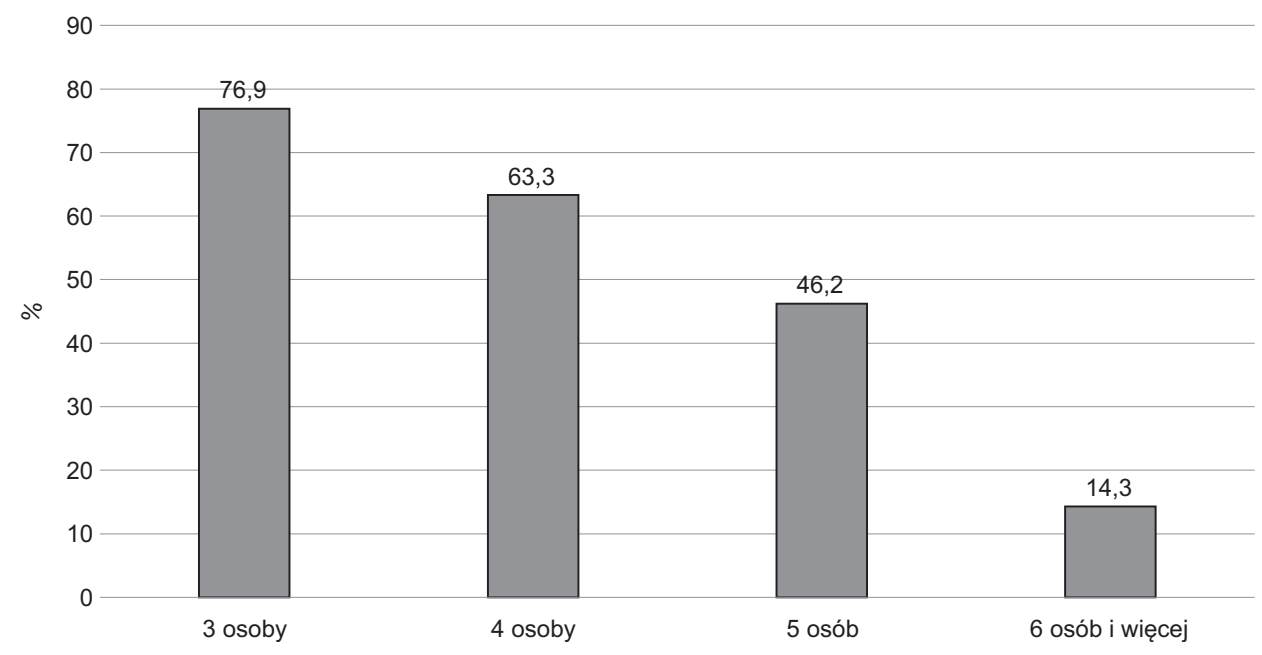

Ryc. 2. Deklarowane turystyczne wyjazdy zagraniczne w zależności od liczebności gospodarstw domowych

Źródło: opracowanie własne na podstawie przeprowadzonych badań.

poznawczych (zob. ryc. 3). Z przeprowadzonych badań wynika, że w podróżach o tych motywach brało udział prawie $58 \%$ respondentów deklarujących wykształcenie wyższe, blisko $27 \%$ osób po szkole średniej oraz tylko $1 / 5$ ankietowanych $\mathrm{z}$ wykształceniem zawodowym.

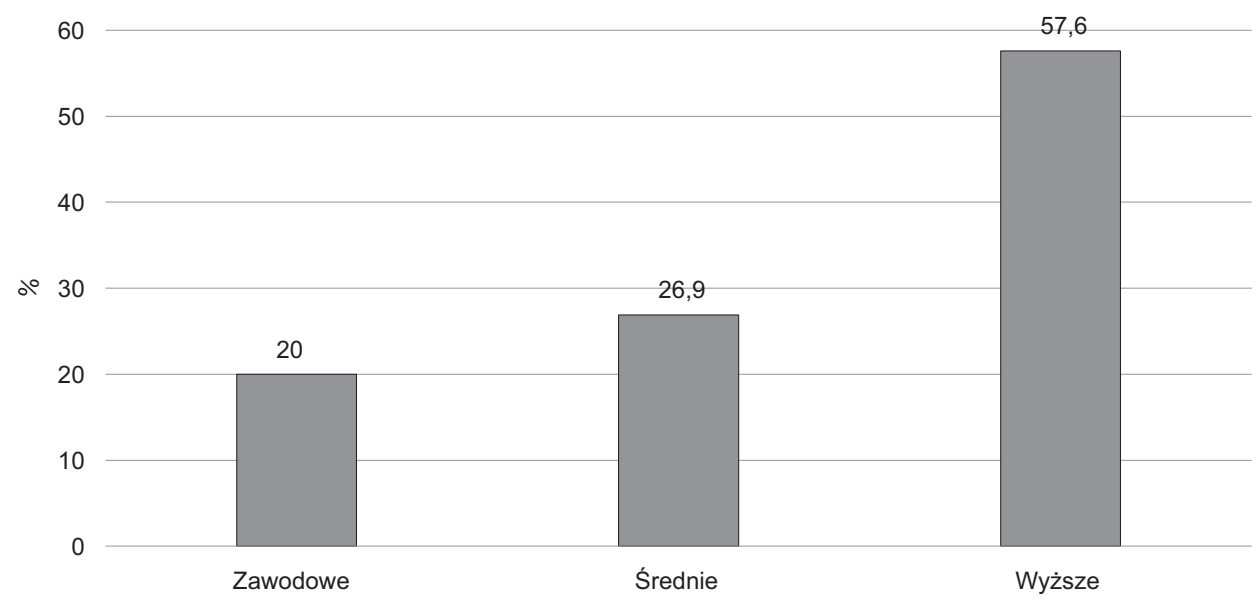

Ryc. 3. Wykształcenie rodziców a motyw poznawczy wyjazdów turystycznych Źródło: opracowanie własne na podstawie przeprowadzonych badań.

Zatem hipotezę $\mathrm{H}_{c,}$ która brzmiała: im wyższe wykształcenie rodzica, tym częściej rodzina wyjeżdża w celach poznawczych, należy uznać za prawdziwą. 


\section{Zakończenie}

Z analizy danych pozyskanych z sondażu diagnostycznego wynika, że postawiona na wstępie niniejszego rozdziału teza główna jest właściwa - po zaspokojeniu potrzeb podstawowych na pewnym poziomie rodziny mogą sobie pozwolić na konsumpcję według upodobania, a w jej ramach na aktywność turystyczną lub częstsze jej podejmowanie. Potwierdzeniem słuszności tego stwierdzenia jest zwłaszcza pozytywna weryfikacja pierwszej z hipotez cząstkowych: wraz ze wzrostem miesięcznego dochodu na członka rodziny wzrasta częstotliwości wyjazdów turystycznych. Jeśli jednak przyjąć, że wyjazd zagraniczny jest z reguły droższy niż wyjazd krajowy, to również druga z hipotez cząstkowych: im liczniejsze gospodarstwo domowe, tym rzadziej jego członkowie podróżują za granicę, potwierdza tezę główną opracowania. Jeśli z kolei założyć, że wyższe wykształcenie pociąga za sobą wyższe dochody, to również ostatnia z hipotez cząstkowych: im wyższe wykształcenie rodzica, tym częściej rodzina podróżuje w celach poznawczych, pozytywnie weryfikuje tezę główną pracy.

$\mathrm{Z}$ analizy wynika ponadto, że aktywność turystyczną beneficjentów programu socjalnego Rodzina 500+ w Polsce determinują takie ich cechy socjodemograficzne, jak: płeć, wykształcenie, liczba osób w gospodarstwie domowym i dochód na członka rodziny. Spośród tych cech najważniejsze okazało się wykształcenie było ono istotnie skorelowane $\mathrm{z}$ wszystkimi badanymi zmiennymi. Trzeba $\mathrm{w}$ tym miejscu zaznaczyć, że omówione badania miały charakter pilotażowy i objęto nimi tylko nielicznych świadczeniobiorców programu Rodzina 500+. Należy jednak je kontynuować, gdyż znajomość zidentyfikowanych zależności może mieć duży wpływ na kształtowanie planów rozwoju społeczno-ekonomicznego w Polsce, a prawidłowe ich rozpoznanie i monitorowanie pozwoli na właściwe dopasowanie oferty turystycznej do potrzeb rodzin z dziećmi.

\section{Literatura}

Brzęczek T. (2019). Ocena programu socjalnego „Rodzina 500+” w świetle teorii konsumenta. Zeszyty Naukowe Politechniki Poznańskiej, Organizacja i Zarządzanie, 80: $7-17$.

Dziwosz E. (2017). Minusy Programu 500 Plus. Zeszyty Naukowe Politechniki Śląskiej, Organizacja i Zarządzanie, 104: 209-216.

Fic M., Fic D., Ropuszyńska-Surman E. (2016). Pułapka średniego dochodu zagrożeniem dla rozwoju gospodarki polskiej. Problemy Współczesnej Ekonomii, Studia i Prace WNEIZ US, 44(3): 127-139.

Jodko M. (2017). Demografia a przyszłość finansów publicznych w Polsce. Studia Ekonomiczne, Zeszyty Naukowe Uniwersytetu Ekonomicznego w Katowicach, 310: 80-90.

Liszatyński D. (2017). Analiza skutków społeczno-ekonomicznych wprowadzenia programu „Rodzina 500+”. Humanum, 27(4): 209-219.

Magda I., Kielczewska A., Brandt N. (2018). The „Family 500+” child allowance and female labour supply in Poland. IBS Working Paper, 1: 2-18. 
Organiściak-Krzykowska A. (2018). Konsekwencje społeczno-ekonomiczne sytuacji demograficznej w Polsce. W: J. Hrynkiewicz, J. Witkowski, A. Potrykowska (red.), Sytuacja demograficzna Polski jako wyzwania dla polityki społecznej i gospodarczej. Rządowa Rada Ludnościowa, Warszawa, s. 130-144.

Puślecki D. (2016). Polityka wsparcia rodziny czy stymulowanie wzrostu demograficznego w Programie Rodzina 500 plus. Przegląd Politologiczny, 6: 79-91.

Sołdra-Gwiżdż T. (2017). Czy „pułapka niskiej dzietności” w województwie opolskim? Perspektywa socjologiczna. Studia Ekonomiczne, Zeszyty Naukowe Uniwersytetu Ekonomicznego w Katowicach, 309: 39-48.

Wojciuk M. (2018). Wpływ programu „Rodzina 500+” na poziom dochodów rozporządzalnych. Prace Naukowe Uniwersytetu Ekonomicznego we Wrocławiu, 529: 412-422.

\section{Sociodemographic determinants of tourist activity of the family $500+$ social program beneficiaries in Poland}

The main aim of the article is to indicate the socio-demographic determinants of tourism activity of the beneficiaries of the Family $500+$ social program in Poland. Based on the results of the research carried out from January to May 2020, using a diagnostic survey among 64 Poles using this type of social support, the main thesis was positively verified that after satisfying basic needs at a certain level, families can afford to consume as they like and within it, tourist activity or taking it up more frequently. Moreover, using the Pearson chi-square dependency test, the following partial hypotheses were confirmed: 1. The frequency of tourist trips increases with the increase in monthly income per family member. 2 . The larger the household, the less frequently its members travel abroad. 3. The higher the parent's education, the more often the family goes away for educational purposes.

The empirical part was preceded by a literature review on the impact of social aid on the economy and the market. 